\title{
Development of methodologies for dimethylaminoethanol glycolate assay in association with sunscreens in dermocosmetic formulation
}

\author{
Daniela Soares Deccache, Elisabete Pereira dos Santos, Lúcio Mendes Cabral, \\ Carlos Rangel Rodrigues, Valéria Pereira de Sousa*
}

Department of Pharmaceutics, College of Pharmacy, Federal University of Rio de Janeiro

\begin{abstract}
DMAE glycolate (DG) and sunscreens have been used associated in anti-aging dermocosmetic formulations. Despite extensive use of these substances, methods for quantification of DG as raw material and in cosmetic formulations, especially when associated, are not described in the literature. RP-HPLC and non-aqueous titration methods, with determination potentiometric end-point (PT), were developed and validated for rapid assay of DG as raw material and in a topic emulsion in association with sunscreens. Both methods are simple, selective, linear, accurate and precise. The PT method was chosen for stability study of DG in the formulation developed. The proposed formulation presented good stability performance as regards aspect, $\mathrm{pH}$, apparent viscosity, and SPF, with less than 5\% of DG degradation compared to initial conditions.
\end{abstract}

Uniterms: DMAE glycolate. Anti-aging dermocosmetic formulations/quantitative analysis. High Performance Liquid Chromatography-RP/quantitative analysis. Non-aqueous potentiometric titration/ quantitative analysis.

Glicolato de DMAE (DG) e protetores solares têm sido utilizados associados em formulações dermocosméticas antiidade. Apesar da ampla utilização dessas substâncias, métodos de quantificação para DG matéria-prima e em formulações cosméticas, especialmente quando associados, não estão descritos na literatura. Neste trabalho foram desenvolvidas e validadas metodologias por CLAE-FR e titulação em meio não-aquoso, com determinação do ponto final por potenciométrica (TP), para a rápida análise de DG matéria-prima e em emulsão tópica em associação com fotoprotetores. Ambos os métodos são simples, seletivos, lineares, exatos e precisos. O método TP foi escolhido para o estudo da estabilidade do DG na formulação desenvolvida. A formulação proposta apresentou um bom desempenho no que se refere a estabilidade, aspecto, $\mathrm{pH}$, viscosidade aparente e SPF, com menos de 5\% degradação do DG comparado as condições iniciais.

Unitermos: Glicolato de DMAE. Formulações dermocosméticas antiidade/análise quantitativa. Cromatografia líquida de alta eficiência-FR/análise quantitativa. Titulação potenciométrica em meio não-aquoso/análise quantitativa.

\section{INTRODUCTION}

Dimethylaminoethanol (DMAE) is an aminoalcohol that presents cholinergic functions (Figure 1). It is an analogue of choline (COL) and acetylcholine (ACH) and has been used since the 1970s as an oral medication to treat some central nervous system diseases related to

*Correspondence: V. P. Sousa. Departamento de Medicamentos, Faculdade de Farmácia, Universidade Federal do Rio de Janeiro, CCS, Bloco B subsolo, sala 15 - Ilha do Fundão - 21941-902 - Rio de Janeiro - RJ, Brasil. E-mail: valeria@pharma.ufrj.br cholinergic neuronal hypo function, such as Alzheimer's disease and tardive dyskinesia. The oral use of DMAE was discontinued due to inconsistent results in clinical trials (Haubrich, Gerber, Pflueger, 1981; Soares, Mcgrath, 1999; Tammemaa, Sailas, Mcgrath, 2004).

Currently, DMAE is widely used as a cosmeceutical compound in many topical anti wrinkle formulations (Cole, Gisoldi, Grossman, 2002; Uhoda et al., 2002; Grossman, 2005). Its dermatological mechanism of action seems to be related to its structural similarity to $\mathrm{ACH}$ and to the presence of non-neuronal $\mathrm{ACH}$ receptors in surface cells of human 


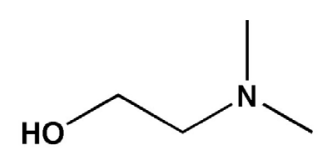

A
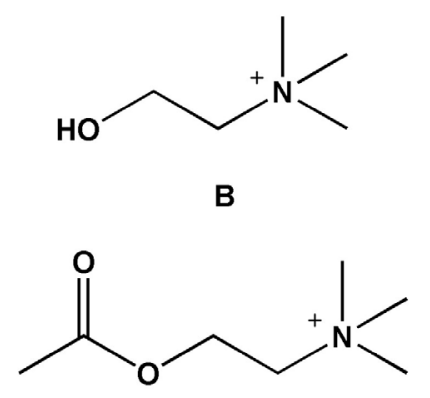

C

FIGURE 1 - Chemical structure of DMAE (A), choline (B), and acetylcholine (C).

skin that could be responsible for mediating a wide variety of cellular activities such as proliferation, differentiation and viability (Klapproth et al., 1997; Grando, 2001; Nguyen et al., 2003). More recent research has investigated the cellular basis of the anti wrinkle effect of DMAE. The DMAE action seems to be related to an increased frequency of vacuolar response, and consequently dilated cells, in DMAE-treated epidermis, probably leading to the improved appearance of wrinkled skin (Morissette, Germain, Marceau, 2007). However, the mechanism of action of the $\mathrm{ACH}$ and DMAE in the skin remains to be elucidated.

First analytical methods described simultaneous analysis of DMAE, ACH and COL in mice and rat plasma using gas chromatography equipped with a rubidium nitrogen flame detector (Zahnizer et al., 1978). The determination of DMAE hydrochloride and COL chloride using cation-exchange HPLC and a conductivity detector was described for a radiomarked preparation (Mishani, Ben-David, Rozen, 2002). These methods are applied to pharmacokinetic studies but not to pharmaceutical quality control. A nuclear magnetic resonance spectroscopic method has also been reported for quantitative determination of DMAE salts, such as maleic, bitartrate and acetamidobenzoate (Batista et al., 2008).

However, a literature survey revealed that there is no method reported for the analysis of DMAE glycolate (DG) in bulk and in pharmaceutical or cosmetic preparation. Nevertheless, many dermatologic preparations using DG have been developed and commercialized. The association of DG with many cosmetic ingredients is frequently prescribed. The association of DMAE with UVA-B sunscreens is especially indicated due to the increase in anti-aging and anti wrinkle effects, facilitating treatment adhesion.
Although it is a frequently prescribed association, there are no reports on its stability and efficiency, mainly due to the absence of analytical methods for DMAE. The absence of available methods for DMAE quantification is principally due to the low molar absorptivity in the UV region, and to lack of chromophore that absorb in the visible region. This renders titration a very appropriate alternative method.

The purpose of the present study was to develop and validate a simple RP-HPLC method with UV detection and a rapid and low cost non-aqueous titrimetric method with potentiometric detection of the equivalence-point for quantitative analysis of DG associated with sunscreens in a cosmetic preparation. The compatibility and stability of the proposed emulsion containing DMAE in association with sunscreens was assessed by changes in the visual aspect, centrifugation, $\mathrm{pH}$, apparent viscosity, sun protective factor (SPF) and DG assay. The stability study was carried out over a 3-month period at room temperature $\left(25^{\circ} \mathrm{C} \pm\right.$ $2{ }^{\circ} \mathrm{C}$ ) and accelerated conditions $\left(40^{\circ} \mathrm{C} \pm 2{ }^{\circ} \mathrm{C}\right)$, under saturated humidity.

\section{MATERIAL AND METHODS}

\section{Chemicals and reagents}

DMAE glycolate was kindly supplied by Embrafarma and DEG (São Paulo, Brazil). The purity of the working standard (Embrafarma) was confirmed by $\mathrm{pH}$, UV spectroscopy and titration. The octyl methoxycinnamate (MTO) and octocrylene (OCT) sunscreens were obtained from Spectrum Química (Rio de Janeiro, Brazil), and benzophenone-3 (BZF-3) sunscreen from Deg (São Paulo, Brazil).

Acetonitrile were HPLC grade and was obtained from Tedia Brazil (Rio de Janeiro, Brazil). Glacial acetic acid, perchloric acid, acetic anhydride, monobasic potassium phosphate, BHT, and sodium hydroxide were supplied from Vetec (Rio de Janeiro, Brazil). All chemicals and reagents were of analytical grade. Distilled water, purified by a Millipore Milli-Q system, was used for the preparation of all solutions.

\section{Formulation}

The formulation (Table I) was prepared by dispersing, with constant stirring, Structure $\mathrm{XL}^{\circledR}$ in purified water at $70{ }^{\circ} \mathrm{C}$ containing Phenochem ${ }^{\circledR}$. The sunscreens (octyl methocynnamate, benzophenone-3 and octocrylene) and BHT were homogenized together and subsequently mixed with emulgin VL $75^{\circledR}$. This oily phase was added to the aqueous phase by emulsification in a Fisatom 713 D shaker 
TABLE I - Components of the formulation studied

\begin{tabular}{|c|c|}
\hline Components & Concentration (w/w, \%) \\
\hline DMAE glycolate & 5.0 \\
\hline Octyl methoxycinnamate & 2 \\
\hline Benzophenone-3 & 2 \\
\hline Octocrylene & 2 \\
\hline Phenochem $^{\circledR a}$ & 0.5 \\
\hline Eumulgin VL $75^{\circledR b}$ & 3 \\
\hline Structure XL ${ }^{\circledR c}$ & 5 \\
\hline BHT & 0.05 \\
\hline Fragrance & 0.2 \\
\hline Water q.s. to & 100 \\
\hline
\end{tabular}

INCI designation: ${ }^{a}$ Dispersion of phenoxyethanol, methylparaben, ethylparaben, butylparaben, propylparaben and isobutylparaben, blauryl glucoside, polyglyceryl-2 dipolyhydroxystearate, and glycerin, ${ }^{c}$ Polymeric non-ionic emulsifier (hydroxypropyl starch phosphate). Q.s., sufficient quantity.

(São Paulo, Brazil) at approximately 800 rpm followed by a high dispersion with an Ultra Turrax T18 basic shaker (Guangzhou, China) at $6000 \mathrm{rpm}$. DG was added to the emulsified formulation at $40^{\circ} \mathrm{C}$. Placebo formulation was prepared using all excipients without DG.

\section{HPLC Instrumentation and analytical conditions}

Liquid chromatography analyses were performed using a Shimadzu system (Kyoto, Japan) consisting of a binary pump model LC-10AD, auto sampler model SIL$10 \mathrm{AD}$, set to $10 \mu \mathrm{L}$ of injected sample volume, equipped with a diode array detector model SPD-M10A, set at $205 \mathrm{~nm}$. Data acquisition was performed by the Class-VP version 6.1 software. The analyses were carried out on a Shimpack ${ }^{\circledR}$ CLC-ODS $C_{18}$ column $(250$ x 4.6 mm i.d., $5 \mu \mathrm{m}$ particle size; Shimadzu) using isocratic elution at room temperature $\left(25 \pm 2{ }^{\circ} \mathrm{C}\right)$. Different mobile phases were tested in order to set the best conditions for separating DG from the other emulsion constituents. The optimal composition of the mobile phase was acetonitrile:phosphate buffer $(\mathrm{pH} 7.4 ; 0.05 \mathrm{M})(5: 95, \mathrm{v} / \mathrm{v})$ used at a flow rate of $1.0 \mathrm{~mL} / \mathrm{min}$. The mobile phase was freshly prepared and filtered through a $0.45 \mu \mathrm{m}$ membrane filter Millipore (Massachusetts. USA).

The DG amount in the formulation was extracted by dissolving the emulsion in acetonitrile:potassium phosphate $(\mathrm{pH} 7.4 ; 0.05 \mathrm{M})(1: 1, \mathrm{v} / \mathrm{v})$ solution under sonication for $5 \mathrm{~min}$. The obtained sample was diluted, filtered and assayed.

\section{Working solution}

Stock standard solutions of $20 \mathrm{mg} / \mathrm{mL}$ were freshly prepared by accurately weighing out approximately $1.5 \mathrm{~g}$ of DG (about $70.1 \%$ purity) into a $50 \mathrm{~mL}$ volumetric flask and adding the extraction solution acetonitrile:phosphate buffer to volume $(\mathrm{pH} 7.4 ; 0.05 \mathrm{M})(1: 1, \mathrm{v} / \mathrm{v})$. These standard solutions were further diluted to obtain five working standards at the concentration of 400,600, 800, 1000 and $1200 \mu \mathrm{g} / \mathrm{mL}$ of DG, covering $80-120 \%$ of the working concentration used to quantify the DG in the proposed formulation. All solutions were prepared in triplicates.

\section{Assay sample preparation}

For recovery and precision studies, the matrix placebo of the emulsion was spiked with DG. It was accurately weighed into a $25 \mathrm{~mL}$ volumetric flask in order to obtain quantities of about 80,100 and $120 \%$ of the assay level, corresponding to 4,5 and $6 \%$ DG. The samples were extracted by addition of $15 \mathrm{~mL}$ of the extractor solution acetonitrile:phosphate buffer $(\mathrm{pH} 7.4 ; 0.05 \mathrm{M})(1: 1$, $\mathrm{v} / \mathrm{v}$ ), sonicated for $5 \mathrm{~min}$ and brought to volume with the same solvent. An aliquot of $5.0 \mathrm{~mL}$ of each solution was transferred to a $25 \mathrm{~mL}$ volumetric flask. These solutions were further diluted with extractor solution to obtain the working samples in triplicate at the concentrations of 600 , 800 and $1000 \mu \mathrm{g} / \mathrm{mL}$, respectively. Prior to injection, all the samples were passed through a $0.45 \mu \mathrm{m}$ membrane filter. Identification of peaks in the formulation sample was based on the comparison of retention times of DG in standard solution. Peak identity was confirmed by UVVis spectra. The area data was normalized to the sample weight. Data were determined from an average of at least 2 determinations of 3 samples.

\section{PT Instrumentation and analytical conditions}

The DG purity and DG assay in formulation associated with sunscreens in an emulsion preparation were determined using the neutralization titration method in non-aqueous solvent. The point of equivalence was potentiometrically determined. The analyses were carried out on an automatic titrator Mettler Toledo DL25 system (New York, USA) equipped with CV4 Mettler Toledo combined glass electrode $(\mathrm{KCl} 3 \mathrm{M} / \mathrm{LiCl} 3 \mathrm{M}$ in acetic acid), operated at room temperature $\left(25 \pm 2{ }^{\circ} \mathrm{C}\right)$. Samples of the formulation studied were mixed ( $2 \mathrm{~min}$ ) in the titration vessel using glacial acetic acid:acetic anhydride $(50: 1, \mathrm{v} / \mathrm{v})$, as non-aqueous solvents. Standardization of the titrant perchloric acid $(0.1 \mathrm{~N})$ was performed in tripli- 
cate immediately before each analysis using the primary standard potassium biftalate. The analysis factor was 16.4 mg of DG per $1 \mathrm{~mL}$ of $\mathrm{HClO}_{4} 0.1 \mathrm{~N}$.

\section{Assay sample preparation}

The recovery and precision of the methods were assessed by analyzing samples of the matrix placebo spiked with DG. It was accurately weighed in triplicate directly into the titration vessel using glacial acetic acid:acetic anhydride $(50: 1, \mathrm{v} / \mathrm{v})$ as the solvent and mixed about $2 \mathrm{~min}$ prior to potentiometric titration. Samples were prepared in order to obtain quantities about 80,100 and $120 \%$ of the assay level, corresponding to 4,5 and $6 \% \mathrm{DG}$, and theoretical mass of 80,100 and $120 \mathrm{mg} \mathrm{DG}$, respectively.

\section{Validation procedure}

The methods were validated in accordance with Brazilian guidelines and the International Conference on Harmonization guidelines for validation of analytical procedures (Brasil, 2003; ICH, 2005).

\section{Specificity}

HPLC specificity was assessed by comparing the samples' chromatograms with those obtained from placebo corresponding to $1000 \mu \mathrm{g} / \mathrm{mL}$ DG. For the PT method, the specificity was assessed by comparing the volume of titrant consumed in placebo and in solvent titration, with those obtained from sample titration, considering the formulation theoretical level of $100 \%$ DG.

\section{Linearity}

The calibration curves were constructed with five concentrations over the range of $400-1200 \mu \mathrm{g} / \mathrm{mL}$, for the HPLC method, and with six concentrations over the range of 40-140 mg DG for the PT method, both prepared in triplicates, in three days. For the HPLC method, the peak area ratio of DG was plotted versus the corresponding concentration $(\mu \mathrm{g} / \mathrm{mL})$ to obtain the calibration graph. For the PT method, the ratio of titrant volume $(\mathrm{mL})$ versus corresponding DG concentration (mg) was used. Linearity was evaluated using linear regression analysis by the least square regression method. The standard curves were evaluated for inter-day linearity.

The degree of linearity was assessed considering the correlation coefficient, intercept, slope, and the standard error for the slope and the intercept.

\section{Precision and accuracy}

The precision and accuracy of the methods were determined by analyzing samples of matrix placebo spiked with DG, prepared in triplicates, at three concentration levels: 80,100 and $120 \%$ of the working concentration. Formulations containing 4, 5 and $6 \%$ of DG were prepared. Samples of these formulations were prepared corresponding to DG theoretical mass of 80,100 and $120 \mathrm{mg}$ for PT method, and using concentrations of 600,800 and $1000 \mu \mathrm{g} / \mathrm{mL}$, for the HPLC method.

Precision was determined by repeatability and reported as \% R.S.D. of replicate measurements. Accuracy was determined by the analyses of a sample of known concentration of DG standard and subsequent comparison of the measured value with the true value. The peak area and the volume of titrant for HPLC and PT methods, respectively, were normalized to the DG sample weight. For the PT method, the volume of titrant was deducted from the blank value.

The injection precision assessment was performed by six replicate injections of the sample solution at the three different levels $(80 \%, 100 \%$ and $120 \%)$ in order to verify area ratios and the retention time of DG.

\section{Limit of detection (LOD) and limit of quantitation (LOQ)}

The parameters LOD and LOQ were determined on the basis of response and slope of the regression equation from three calibration curves obtained at different days for both methods. LOD was calculated as three times the standard deviation of the intercept of the calibration curves, and LOQ as ten times.

\section{Stability study}

The formulation containing 5\% DG (Table I) was prepared and bottled in propylene flasks with $120 \mathrm{~g}$ capacity. The formulation samples were stored at room temperature $\left(25^{\circ} \mathrm{C} \pm 2{ }^{\circ} \mathrm{C}\right)$ and $40{ }^{\circ} \mathrm{C} \pm 2{ }^{\circ} \mathrm{C}$, under saturated humidity, for long and accelerated-term stability, respectively. The samples were kept under controlled temperature and humidity conditions for a period of 3 months and the tests were carried out on the first day and at 15-day intervals.

The stability study of the formulation was performed by evaluation of visual aspects, centrifugation, apparent viscosity, $\mathrm{pH}, \mathrm{SPF}$ and $\mathrm{DG}$ assay. The centrifugation stability was performed using a Beckman Coulter Avanti J 25 centrifuge (Fullerton, USA), at $6000 \mathrm{rpm}$ for $15 \mathrm{~min}$, at $25^{\circ} \mathrm{C}$. The apparent viscosity measurements were carried out under ambient temperature and humidity $\left(25^{\circ} \mathrm{C} \pm 2{ }^{\circ} \mathrm{C}\right.$ and $50 \pm 5 \% \mathrm{RH}$ ) using an analogical Brookfield model LVT (Massachusetts, USA) with LV4 spindle set at $6 \mathrm{rpm}$. 
The measurements of $\mathrm{pH}$ were assessed using a Digimed DM 21 pHmeter, electrode CV1 (São Paulo, Brazil) calibrated immediately before each measure. The assay of DG in the formulation was performed in triplicate by the described PT method. The volume consumed in the blank was deducted from the total volume of analysis.

The assessment of SPF in vitro of the formulation was carried out using the spectrophotometric method (Mansur et al., 1986). The absorbances of a formulation sample were measured in triplicate over the UVB range $(290,295,300,305,310,315$ and $320 \mathrm{~nm})$ using a Shimadzu UV 2401 PC spectrophotometer (Kyoto, Japan). Solutions of all samples were prepared to obtain a concentration of $0.2 \mathrm{mg} / \mathrm{mL}$. A $0.5 \mathrm{~g}$ amount was weighed in a $100 \mathrm{~mL}$ volumetric flask, diluted with $30 \mathrm{~mL}$ ethanol and sonicated for $5 \mathrm{~min}$. The volume was completed using ethanol. A $1 \mathrm{~mL}$ aliquot was transferred to a $25 \mathrm{~mL}$ volumetric flask, and after homogenization this volume was completed with ethanol. The measures were performed in triplicate on the spectrophotometer using ethanol as the reference liquid. The SPF was calculated according to Mansur et al. (1986) using the equation:

$$
S P F_{\text {spectrophtometric }}=C F \times \Sigma_{290}^{320} E E(\lambda) \times I(\lambda) \times A b s(\lambda)
$$

Where: $\mathrm{CF}=$ correction factor $(=10)$; $\mathrm{EE}=$ erythemal effect spectrum; I= solar intensity spectrum; $\mathrm{Abs}=$ absorbance of sunscreen product. The values of EE x I are constants determined by Sayre et al. (1979).

\section{RESULTS AND DISCUSSION}

\section{Validation of HPLC method}

An RP-HPLC method was developed in order to quantify DG in cosmetic formulations. The RP-HPLC is a chromatographic method that uses a non-polar stationary phase, in this case an octadecyl chain linked to a silica surface. Thus, the retention of the analyte depends on the adequate balance of polarity between mobile phase and stationary phase. We therefore worked with mixtures of aqueous buffer and organic solvent to elute the analyte from the column at adequate times. Due to the low molar absorptivity of DMAE in the UV region (205 nm) a higher than normal working concentration was used $(0.8 \mathrm{mg} /$ $\mathrm{mL}$ ). The chromatographic conditions were optimized to provide an assay with adequate performance. The effect of the mobile phase composition and the sample extractor solution on the system suitability studies was investigated. The parameters evaluated were retention time $(R t)$, tailing factor $(T)$, and column efficiency $(N)$. Mobile phases consisting of phosphate buffer $(0.05 \mathrm{M}, \mathrm{pH} 7.4)$ and acetonitrile mixtures at various ratios $(95: 5,98: 2,99: 1,100 \%)$ were tested. The variation of composition of the mobile phase caused considerable changes in the tailing factor as shown in Table II.

The mobile phase selected was a mixture of acetonitrile:phosphate buffer ( $\mathrm{pH} 7.4 ; 0.05 \mathrm{M})$ (5:95, $\mathrm{v} / \mathrm{v}$ ) and the extractor solution was acetonitrile:phosphate buffer ( $\mathrm{pH} 7.4 ; 0.05 \mathrm{M})(1: 1, \mathrm{v} / \mathrm{v})$. These conditions were found to be suitable, increasing the peak symmetry with a short retention time and no interference. Figure 2 shows representative chromatograms of working standard DG and the formulation sample at a concentration of $1000 \mu \mathrm{g} / \mathrm{mL}$.

In order to study the effect of formulation ingredients on quantification of DG, a placebo was prepared. The results revealed no interference of the excipients, which was confirmed through recovery studies.

Five-point calibration curves were constructed on three different days with working standard, and were found to be linear over the range $400-1200 \mu \mathrm{g} / \mathrm{mL}$. The parameters of calibration curves are presented in Table III.

The accuracy results were expressed in terms of percentage recoveries of DG spiked in the matrix placebo samples. The results are summarized in Table IV. The percent DG recoveries in placebo samples were within

TABLE II - System suitability

\begin{tabular}{lcccccc}
\hline Parameter & \multicolumn{3}{c}{ Mobile phase $(\mathrm{v} / \mathrm{v})^{\mathrm{a}}$} & \multicolumn{2}{c}{ Liquid extractor $(\mathrm{v} / \mathrm{v})^{\mathrm{b}}$} \\
\cline { 2 - 7 } & $95: 5$ & $98: 2$ & $99: 1$ & $100 \%$ & ACN $(1: 1)$ & Hexane $(2: 1)$ \\
\hline$R_{t}$ & 2.76 & 2.79 & 2.87 & 2.85 & 2.88 & 2.64 \\
$T$ & 2.1 & 2.2 & 2.1 & 1.06 & 1.2 & 0.69 \\
$N$ & 2868 & 2531 & 1486 & 2402 & 1926 & 1472 \\
\hline
\end{tabular}

The parameters monitored were peak retention time $\left(R_{t}\right)$, tailing factor $(T)$, and theoretical plates $(N)$.

${ }^{a}$ The experiment was performed using mobile phase consisting of phosphate buffer $(0.05 \mathrm{M})$ varying the $\mathrm{ACN}$ ratio. The experiment was carried out using phosphate buffer $(\mathrm{pH} 7.4,0.05 \mathrm{M})$ as mobile phase. ${ }^{\mathrm{b}}$ Tests varying the composition of liquid extractor $\mathrm{ACN}$ $(1: 1, \mathrm{v} / \mathrm{v})$ and hexane $(2: 1, \mathrm{v} / \mathrm{v})$ was performed. The liquid extractor of choice was acetonitrile-phosphate buffer $(\mathrm{pH} 7.4,0.05)$ $(1: 1, \mathrm{v} / \mathrm{v})$. 
the range 102.7 to $104.7 \%$. The assay results indicated that the precision of the proposed method was satisfactory, between 0.45 and $4.06 \%$. The limits of detection
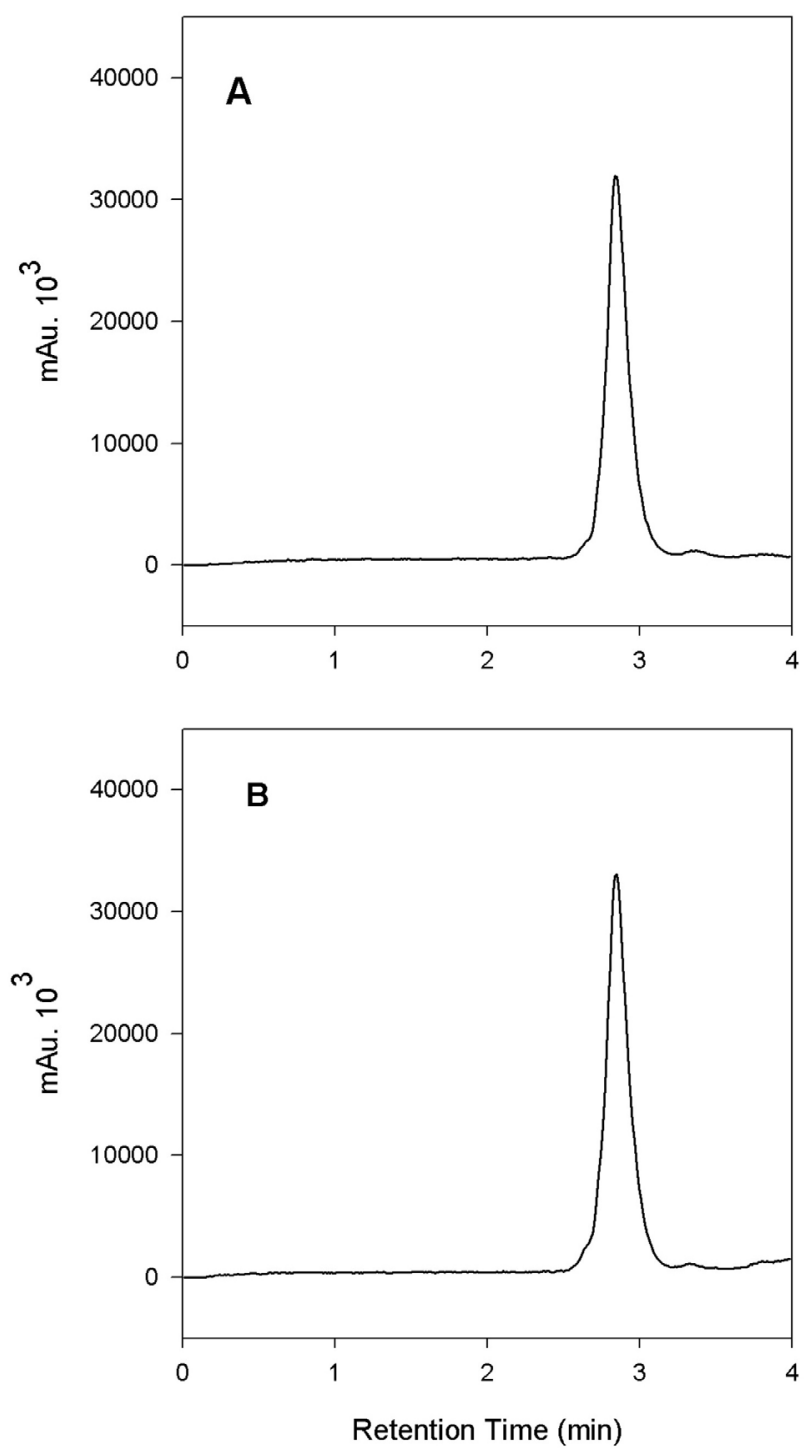

FIGURE 2 - Representative chromatogram of: (A): DG working standard $(1000 \mu \mathrm{g} / \mathrm{mL})$ and $(B)$ : formulation sample $(1000 \mu \mathrm{g} / \mathrm{mL})$.
(LOD) and quantitation (LOQ) calculated were 25.1 and $83.8 \mu \mathrm{g} / \mathrm{mL}$, respectively.

The precision of injection was evaluated by analyzing six replicate injections of three samples with 80 , 100 and $120 \%$ concentration levels. The results showed a R.S.D. of $1.88,0.80$ and $0.28 \%$, respectively. These results indicated good precision of injection. The results obtained from the repeatability study are listed in Table IV.

\section{Validation of PT method}

The PT method proposed in this paper for analysis of DMAE glycolate in dermocosmetic formulation also applies to raw material. The potentiometric titration makes the detection of the equivalence point more accurate. In this case the first derivative of the titration curve was used to obtain the equivalence point. The analysis was performed in glacial acetic acid - an amphiprotic solvent that exerts a leveling effect and enhances the basic properties of the DMAE - and acetic anhydride to react with the water. The organic solvents also promote the complete solubilization of the formulation that contains oily components and favors the extraction of DMAE.

The selectivity of PT titration was determined by placebo and solvent analysis, comparing volumes of titrant used in the sample titration at a $100 \%$ concentration level (Table V). The results showed that the volume of titrant used in the neutralization of placebo $(\sim 3 \%)$ and solvent $(\sim 0.2 \%)$ was low compared to sample analyses, but was deducted from the final value.

A six-point calibration curve was constructed covering a range of 40-140 $\mathrm{mg}$ of DG. Three independent determinations were performed for each concentration. The linear relationship between the ratio of the titrant volume $(\mathrm{mL})$ and DG concentration $(\mathrm{mg})$ was observed, as shown by the results presented in Table III. The correlation coefficient exceeded 0.999 .

The repeatability study indicated an R.S.D. of $0.98 \% .1 .26 \%$ and $0.34 \%$ for the 80,100 and $120 \%$ con-

TABLE III - Calibration curves of the methods

\begin{tabular}{|c|c|c|}
\hline Parameters & HPLC & $\mathrm{PT}$ \\
\hline Linear range & $0.40-1.2 \mu \mathrm{g} / \mathrm{mL}$ & $40-140 \mathrm{mg}$ \\
\hline Regression equation $^{\mathrm{a}}$ & $y=355.2 x-12032.8$ & $y=0.0595 x+0.0199$ \\
\hline Standard error of slope & 5.0 & 0.0115 \\
\hline Standard error of intercept & 2974.4 & $5.8 \times 10^{-5}$ \\
\hline Correlation coefficient $\left(\mathrm{r}^{2}\right)$ & 0.9990 & 0.9999 \\
\hline
\end{tabular}

a $y=b x+a$, where $x$ is the concentration in $\mu \mathrm{g} / \mathrm{ml}, y$ is the peak area for HPLC method, and $x$ is the amount added of DG (mg) and $y$ is the titrant volume for PT method, $a$ is the intercept and $\mathrm{b}$ is the slope $(\mathrm{n}=3) ; \mathrm{SE}=\mathrm{sd} / \sqrt{\mathrm{n}}$. 
TABLE IV - Results of precision and accuracy by HPLC and PT methods $(\mathrm{n}=3)$

\begin{tabular}{|c|c|c|c|c|c|c|}
\hline \multirow{2}{*}{$\begin{array}{l}\text { Concentration } \\
\text { levels (\%) }\end{array}$} & \multicolumn{3}{|c|}{ HPLC } & \multicolumn{3}{|c|}{ PT } \\
\hline & $\begin{array}{l}\text { Amount found } \\
(\mathrm{mg})\end{array}$ & $\begin{array}{c}\text { Mean recovery } \\
(\%, w / w)\end{array}$ & $\begin{array}{c}\text { R.S.D. } \\
(\%)\end{array}$ & $\begin{array}{l}\text { Amount found } \\
(\mathrm{mg})\end{array}$ & $\begin{array}{c}\text { Mean recovery } \\
(\%, w / w)\end{array}$ & $\begin{array}{c}\text { R.S.D. } \\
(\%)\end{array}$ \\
\hline 80 & $\begin{array}{l}86.34 \\
81.01 \\
80.15\end{array}$ & 103.1 & 4.1 & $\begin{array}{l}80.45 \\
81.21 \\
79.62\end{array}$ & 100.5 & 1.0 \\
\hline 100 & $\begin{array}{l}102.45 \\
103.28 \\
102.50\end{array}$ & 102.7 & 0.5 & $\begin{array}{l}100.06 \\
100.92 \\
102.57\end{array}$ & 101.2 & 1.3 \\
\hline 120 & $\begin{array}{c}124.75 \\
123.6 \\
127.67\end{array}$ & 104.6 & 0.7 & $\begin{array}{l}119.63 \\
119.12 \\
118.81\end{array}$ & 99.3 & 0.3 \\
\hline
\end{tabular}

TABLE V - Results obtained for selectivity of PT method

\begin{tabular}{lcc}
\hline Sample & $\begin{array}{c}\text { Volume } \\
(\mathrm{ml}) \pm \text { R.S.D. }(\%)\end{array}$ & $\begin{array}{c}\text { Equivalent of DG } \\
(\mathrm{mg})\end{array}$ \\
\hline Placebo & $0.1844 \pm 0.49 \%$ & 3.05 \\
Solvent & $0.0116 \pm 0.50 \%$ & 0.190 \\
Sample (5\% DG) & $6.05 \pm 1.3 \%$ & 100.1 \\
\hline
\end{tabular}

$\mathrm{N}=3$; mean \pm R.S.D. $\%$.

centration levels, respectively (Table IV). The data for accuracy were expressed in terms of percentage recoveries of DG in placebo-spiked samples. These results are summarized in Table IV. The mean recovery data of DG were within the 99.3 to $101.2 \%$ range, in accordance with the acceptance criteria of the parameter evaluated. The limits of detection (LOD) and quantitation (LOQ) calculated were 2.9 and $9.7 \mathrm{mg}$, respectively.

\section{Stability study}

The stability of the proposed formulation containing
DG and sunscreens in association was verified after storage of the samples at room temperature $\left(25^{\circ} \mathrm{C} \pm 3{ }^{\circ} \mathrm{C}\right)$ and under accelerated conditions $\left(40^{\circ} \mathrm{C} \pm 2{ }^{\circ} \mathrm{C}\right)$ of saturated humidity. The stability was evaluated considering the changes observed in the visual aspect, centrifugation, $\mathrm{pH}$, apparent viscosity, SPF and DG assay. The PT method was chosen to verify the DG assay in the samples due to its efficacy and simplicity.

Apparent viscosity values were within the range $21.5-23.0 \times 10^{3} \mathrm{cps}$, for the samples stored under ambient conditions, and $21.0-22.0 \times 10^{3} \mathrm{cps}$, for the samples stored under accelerated conditions. Statistical analysis entailed application of the $t$ test to compare apparent viscosity values (Table VI). Results showed no statistical differences $(p=0.0831)$ between time and conditions of storage. The samples were stable after centrifugation, presenting no phase separation $\left(600 \mathrm{rpm}, 15 \mathrm{~min} ; 25^{\circ} \mathrm{C}\right.$ ). However, a slightly yellowish powder was observed after centrifugation on the $90^{\text {th }}$ day. The formulation was a homogeneous and consistent emulsion, white in colour, that met acceptance criteria related to appearance and physical attributes during storage under both conditions.

TABLE VI - Results of stability studies for DG assay and $\mathrm{pH}$ verified in stored (A) room samples and (B) accelerated conditions using PT method

\begin{tabular}{|c|c|c|c|c|c|c|}
\hline \multirow{2}{*}{ Time (days) } & \multicolumn{2}{|c|}{ DG found $(\%)(\mathrm{w} / \mathrm{w})^{\mathrm{a}} \pm$ R.S.D. } & \multicolumn{2}{|c|}{ Viscosity $(\mathrm{cps})^{\mathrm{b}}$} & \multicolumn{2}{|c|}{$\mathrm{pH}^{\mathrm{b}}$} \\
\hline & A & $\mathrm{B}$ & A & $\mathrm{B}$ & A & $\mathrm{B}$ \\
\hline 0 & $5.4 \pm\left(6 \times 10^{-40} \%\right)$ & $5.4 \pm\left(6 \times 10^{-40} \%\right)$ & 22000 & 22000 & 4.5 & 4.5 \\
\hline 15 & $5.4 \pm\left(5 \times 10^{-40} \%\right)$ & $5.4 \pm(0.00 \%)$ & 23000 & 22000 & 4.4 & 4.3 \\
\hline 30 & $5.5 \pm\left(4 \times 10^{-40} \%\right)$ & $5.5 \pm\left(1 \times 10^{-30} \%\right)$ & 21500 & 21500 & 4.4 & 4.4 \\
\hline 60 & $5.4 \pm\left(5 \times 10^{-40} \%\right)$ & $5.4 \pm\left(6 \times 10^{-4 \%} \%\right)$ & 22000 & 21500 & 4.3 & 4.3 \\
\hline 90 & $5.4 \pm\left(2 \times 10^{-40} \%\right)$ & $5.46 \pm\left(1 \times 10^{-30} \%\right)$ & 23000 & 21000 & 4.3 & 4.3 \\
\hline
\end{tabular}

${ }^{a}$ Mean of three determinations, ${ }^{b} \mathrm{P}>0.05$. (A) Formulations stored at room temperature; (B) Formulations stored at $40{ }^{\circ} \mathrm{C} \pm 2{ }^{\circ} \mathrm{C}$ under saturated humidity. 
The experimental values of $\mathrm{pH}$ are summarized in Table VI, showing no significant changes during storage time under both conditions compared to controls (initial time) ( $p>0.05)$. It is important for a dermocosmetic to present a stable $\mathrm{pH}$ indicating chemical stability and safety for dermatological use.

The SPF in vitro assay (Figure 3 ) demonstrated a loss of $12.8 \%$ for the sample stored at room temperature $(\mathrm{p}<0.001)$ and $15.5 \%$ under accelerated condition $(p<0.001)$. According to Santos and cols, the analysis of sunscreen formulations containing SPF 8 corresponds to $87.5 \%$ of absorbed UVB radiation, and there is no significant difference regarding percentage of absorbed UVB between formulations in the 6-8 SPF range (Mansur et al., 1986; Santos et al., 1998). Statistical analysis ( $t$ test) demonstrated no significant differences comparing the results obtained at different storage conditions over the study period $(\mathrm{p}>0.05)$.

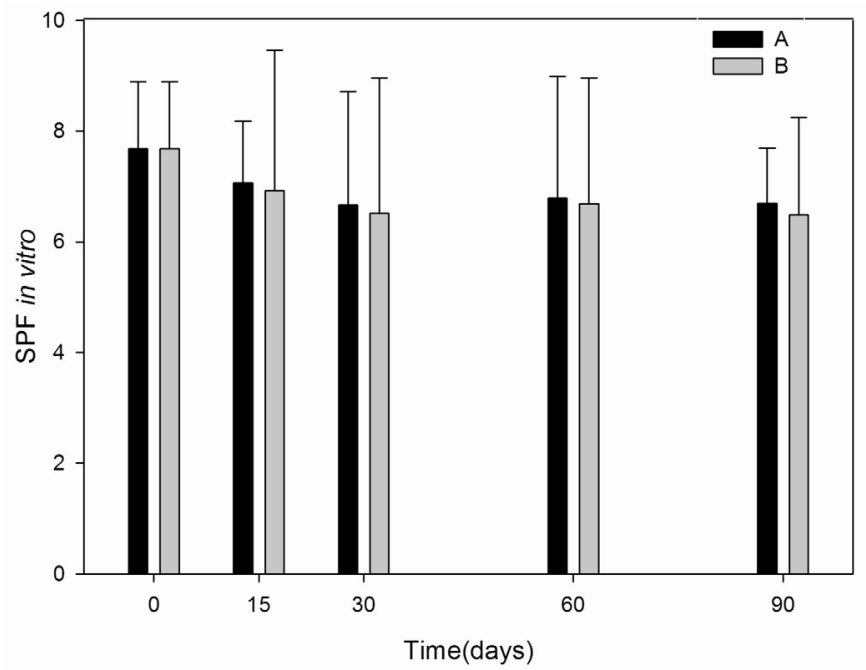

FIGURE 3 - Values of SPF in vitro measured during the stability study. (A): formulations stored at room temperature; (B): formulations stored under accelerated conditions.

The DG assay (Table VI) showed less than 5\% decay from its initial value under both storage conditions, satisfying the ICH acceptance criteria (ICH, 2003, 2004). This data was confirmed by the evidence of no loss of content of DG in the formulation studied using HPLC methodology comparing the first day and $90^{\text {th }}$ day at room temperature. The stability of DG raw material was also studied and no loss was observed during the same period. These results demonstrated that DG possesses compatibility and stability when associated with sunscreens in the developed formulation. This association is useful to improve antiaging effects in dermocosmetic formulations.

\section{CONCLUSION}

The proposed methods are a simple and rapid alternative for quantifying DG in raw material and in formulations. These methods are linear, specific, accurate and precise. Both methodologies demonstrated satisfactory performance considering the simple working conditions established. The chromatographic run time of $2.7 \mathrm{~min}$ allows the analysis of a large number of samples in a short period of time. The titrimetric method is a very simple and low cost method of analyzing DG raw material and dermocosmetic formulations. The proposed formulation, associating DG with sunscreens, demonstrated good stability performance for the analyzed parameters.

\section{REFERENCES}

BATISTA, I.A.; GONÇALVES, M.I.; SINGH, A.K.; HACKMANN, E.R.M.K.; SANTORO, M.I.R.M. Quantitative determination of dimethylaminoethanol in cosmetic formulations by nuclear magnetic resonance spectroscopy. J. AOAC Int., v.91, n.6, p.1303-1308, 2008.

BRASIL. Agência Nacional de Vigilância Sanitária. RE n 899 , Guia de validação de métodos analíticos e bioanalíticos. Brasília, 29 de Maio de 2003, p.1-16.

COLE, C.A; GISOLDI, E.M.; GROSSMAN, R.M. Clinical and consumer evaluations of improved facial appearance after 1 month use of topical dimethylaminoethanol. In: ANNUAL MEETING AMERICAN ACADEMY DERMATOLOGY, 60, New Orleans, 2002. Anais. New Orleans: AAD, 2002. p.1-4.

GRANDO, S.A. Receptor-mediated action of nicotine in human skin. Int. J. Dermatol., v.40, n.11, p.691-693, 2001.

GROSSMAN, R. The Role of dimethylaminoethanol in cosmetic dermatology. Am. J. Clin. Dermatol., v.6, n.1, p.39-47, 2005.

HAUBRICH, D.R.; GERBER, N.H.; PFLUEGER, A.B. Deanol affects choline metabolism in peripheral tissues of mice. $J$. Neurochem., v.37, n.2, p.476-482, 1981.

INTERNATIONAL CONFERENCE ON HARMONIZATION. ICH. Evaluation of Stability Data Q1E. US FDA Federal Register, v.69, n.110, June 8, 2004. p 32010-32011. 
INTERNATIONAL CONFERENCE ON HARMONIZATION. ICH. Stability Testing of new Drug Substances and Products Q1A (R2). US FDA Federal Register, v.68, n.225, November 21, 2003, p.65717-65718.

\section{INTERNATIONAL CONFERENCE ON HARMONIZATION.} ICH. Validation of analytical procedures: text and methodology Q2(R1), Geneva, Switzerland, November, 2005, p.1-13.

KLAPPROTH, H.; REINHEIMER, T.; METZEN, J.; MÜNCH, M.; BITTINGER, F.; KIRKPATRICK, C.J.; HÖHLE, K.D.; SCHEMANN, M.; RACKÉ, K.; WESSLER, I. Nonneuronal acetylcholine, a signaling molecule synthesized by surface cells of rat and man. Naunyn-Schmiedeberg's Arch. Pharmacol., v.355, p.515-523, 1997.

MANSUR, J.S.; BREDER, M.N.R.; MANSUR, M.C.D.; AZULAY, R.D. Determinação do fator de proteção solar por espectrofotometria. An. Bras. Dermatol., v.61, n.3, p.121-124, 1986.

MISHANI, E.; BEN-DAVID, I.; ROZEN, Y. Improved method for the quality assurance of [C-11] choline. Nucl. Med. Biol., v.29, n.3, p.359-362, 2002.

MORISSETTE, G.; GERMAIN, L.; MARCEAU, F. The antiwrinkle effect of topical concentrated 2-dimethylaminoethanol involves a vacuolar cytopathology. Br. J. Dermatol., v.156, n.3, p.433-439, 2007.

NGUYEN, V.T.; ARREDONDO, J.; CHERNYAVSKY A.I.; KITAJIMA, Y.; GRANDO, S.A. Keratinocyte acetylcholine receptors regulate cell adhesion. Life Sci., v.72, n.18, p.2081-2085, 2003.
SANTOS, I.B.; SANT'ANNA D.; CARVALHO, J.; MENDONCA, M.; DOS REIS, V.M.; RODRIGUES DE FRANCA, E. Filtros solares:normas de utilização. Anais Bras. Dermatol., v.73, n.2, p.5-9, 1998. (Congresso Brasileiro De Dermatologia, 52, Brasília, 1997).

SAYRE, R.M.; AGIN, P.P.; LEVEE, G.J.; MARLOWE, E. Comparison of in vivo and in vitro testing of sunscreening formulas. Photochem. Photobiol., v.29, n.3, p.559-566, 1979.

SOARES, K.V.S.; MCGRATH, J.J. The treatment of tardive dyskinesia: a systematic review and meta-analysis. Schizophr. Res., v.39, n.1, p.17-18, 1999.

TAMMENMAA, I.A.; SAILAS, E.; MCGRATH, J.J.; SOARES-WEISER, K.; WAHLBECK, K. Systematic review of cholinergic drugs for neuroleptic-induced tardive dyskinesia: A meta-analysis of randomized controlled trials. Prog. Neuro-Psychopharmacol. Biol. Psychiatry, v.28, n.7, p.1099-1107, 2004.

UHODA I.; FASKA, N.; ROBERT, C.; CAUWENBERGH, G.; PIÉRARD, G.E. Split face study on the cutaneous tensile effect of 2-dimethylaminoethanol (deanol) gel. Skin Res. Technol., v.3, n.3, p.164-167, 2002.

ZAHNISER, N.R.; KATYAL, S.L.; SHIN, T.M.; HANIN, I.; MOOSSY, J.; MARTINEZ, A.J.; LOMBARDI, B. Effects of N-methylaminoethanol and $\mathrm{N}, \mathrm{N}$-dimethylaminoethanol in the diet of pregnant rats on neonatal rat brain cholinergic and phospholipid profile. J. Neurochem., v.30, n.6, p.12451252, 1978.

Received for publication on $27^{\text {th }}$ July 2009. Accepted for publication on $24^{\text {th }}$ March 2010. 